DOI: 10.30519/ahtr.734339

Advances in Hospitality and Tourism Research (AHTR)

\title{
ANALYSIS OF FACTORS AFFECTING HEALTH TOURISM PERFORMANCE USING FUZZY DEMATEL METHOD
}

\author{
Fahriye MERDIVENCİ \\ Department of International Trade and Logistics, Akdeniz University, Turkey \\ ORCID: 0000-0001-8956-7051 \\ Hatice KARAKAŞ ${ }^{1}$ \\ Department of Tourism Management, Akdeniz University, Antalya, Turkey \\ ORCID: 0000-0001-5893-1199
}

\begin{abstract}
In health tourism, an important sub-branch of the tourism sector, the increase in the number of organizations in the service industry in response to increasing demand has led institutions to transform in line with global standards to gain a competitive advantage. Today, due to the steady increase in its share in the sector, it is necessary to establish an assessment infrastructure to measure health tourism performance. This study suggests an infrastructure for determining the factors affecting health tourism. There is no widely accepted standard assessment methodology in determining criteria affecting tourism performance in the literature. However, with a standard assessment structure, it can be possible to rank the achievement of the organizations serving health tourism. Therefore, the Fuzzy DEMATEL method is used as a multi-criteria decisionmaking approach based on fuzzy logic to determine the factors affecting health tourism performance. This study contributes to the literature in terms of presenting the criteria for the assessment of the health tourism performance in a standard structure for researchers, and in which dimensions the organizations should consider their performance.
\end{abstract}

Article History

Received 8 May 2020

Revised 4 October 2020

Accepted 8 October 2020

Keywords

Tourism performance

Health tourism

Fuzzy logic

DEMATEL method

\footnotetext{
${ }^{1}$ Address correspondence to Hatice KARAKAŞ, Department of Tourism Management, Tourism Faculty, Akdeniz University, Antalya, TURKEY. E-mail: haticekarakas@akdeniz.edu.tr
} 


\section{INTRODUCTION}

The tourism sector in Turkey, and in the world, is rapidly developing and transforming into a big market, with alternative tourism types also emerging. Creating new jobs, increasing revenues, and making new investments in this sector is considered a way for the development of the regional and national economy. This requires the knowledge of what the main factors affecting tourism performance are (İlban \& Yıldırım, 2017). Based on the general performance definition, tourism performance (Croes, 2005; Nair, 2013; Benito et al., 2014; Aissa \& Goaied, 2017) is defined as the evaluation of all efforts made in the realization of the sector's objectives. There is an increase in health-based goals among the most common tourist travels. Tourists in health tourism activities tend to participate in many of the general touristic activities, in addition to the medical services they receive. The increase in the popularity of health tourism reflects on the economic value created by the industry, which highlights it among other alternative types in terms of return on tourism (Bookman \& Bookman, 2007). Reducing the individual and public burden of health care costs in developed countries also creates opportunities for developing countries in the understanding of health tourism (Turner, 2007). This study aims to demonstrate the relationship between the criteria affecting health tourism performance. A performance criterion is a measure that can generate quantitative value by considering single and multiple aspects to indicate the level of performance (Parida \& Kumar, 2006). In the literature, many researchers emphasize the need for a study that defines tourism performance criteria and ranks their relative importance (Assaf \& Josiassen, 2012).

Health tourism includes taking advantage of different holiday opportunities in parallel with travel to tourist destinations, as well as receiving a specific health service. Health tourism around the world is recognized as one of the earliest forms of tourism, practiced since antiquity (Ross, 2001; Bookman \& Bookman, 2007; Draghici et al., 2016). The idea that vacation enhances physical and emotional well-being, together with the accessibility of international health services, as an important component of the modern industry, continues to support the emergence of health tourism as a well-designed concept (Goodrich \& Goodrich, 1987; Heung et al., 2010).

Under the concept of health tourism, four tourism sub-markets are examined, including accessible tourism, medical tourism, thermal tourism and senior tourism. Each sub-market has its own characteristics. However, basically, within the scope of health tourism, the expectations of the tourists 
differ from other mass tourists since they need special and qualified tourist products (Tontus, 2016). Therefore, the motivations of travelers for health tourism are based on individual wellness. The product of health tourism is multifaceted, and tourists traveling for health are demanding to benefit from a wide range of services in terms of the conditions and benefits. Underlying factors of general trends are their interest in healthy lifestyles and willingness to spend on health.

For many years, people have been traveling to developing countries to get high quality health care at affordable prices from developed countries. Another purpose of medical tourists in destinations such as Turkey, India, Hungary, and Thailand is to benefit from health services and treatment in the major tourist centers, while combining it with participation in tourism activities (Saleh et al., 2015). Deloitte (2014) also emphasizes that one of the biggest reasons for choosing a foreign country for healthcare is cost. Turkey, in terms of the price of health care, has a number of competitive advantages compared with the US and Europe. Although there is a lot of literature on the competitiveness of medical tourism, it does not describe the framework of international competitiveness (Kilavuz, 2018). However, as discussed, countries with positive destination characteristics such as cultural and historical areas, beaches, political and economic stability, hospitality, service quality, are more likely to stand out in this race. Turkey is one of the most attractive countries in the world considering its destination image characteristics. For this reason, Turkey has a strategic advantage in terms of attractiveness as a tourist destination and health services, compared to other destinations.

When health tourism is analyzed in terms of service delivery, it is divided into two groups: medical and wellness (Reed, 2008; Erfurt-Cooper \& Cooper, 2009; Loh, 2014; Smith \& Puczko, 2014). Medical tourism includes travel across international borders, especially for the purpose of receiving medical care. The overall motivation of those participating in this type of tourism is based on reasons such as cost savings and/or treatment taking less time at medical tourism destination than the waiting time for treatment in their origin country (Snyder et al., 2011). The increase in technological accessibility has also led to the emergence of new companies (i.e., medical travel agencies) that mediate and provide assistance between international patients and hospital networks, thereby further facilitating growth. As the popularity and reputation of health tourism continue to grow, opportunities for both hospitality and the health sector increase (Hume \& De Micco, 2007). 
This article is organized as follows: firstly, the theoretical framework is explained in the introduction. The second chapter reviews the literature about the tourism performance. The third chapter explains the fuzzy DEMATEL method, while the fourth chapter suggests the method applied for the prioritization of the criterion that will assess the tourism performance. Finally, the fourth chapter provides conclusions and suggestions regarding this study.

\section{LITERATURE REVIEW}

Decision making is the study of identifying and selecting alternatives for the judgments of decision-makers. Prioritizing factors and sub-factors affecting tourism performance effectiveness is regarded as a multi-criteria decision-making problem (Do \& Chen, 2013). Multi-Criteria DecisionMaking studies and other research related to tourism performance reviewed in the literature are summarized below.

Zopounidis et al. (2010) used PROMETHEE II, one of the multicriteria decision-making methods for a comparative analysis of tourism performance in the Mediterranean region. In their study, 13 different criteria containing qualitative and quantitative information were discussed. Wadongo et al. (2010) focused on the managerial characteristics by concentrating on the importance and usage levels of performance indicators in the hospitality industry in Kenya. Performance indicators were listed as competitiveness, financial performance, service quality, flexibility, resource utilization, supplier performance and environmental perspective.

Wang et al. (2016) used the Fuzzy DELPHI and Fuzzy Analytic Hierarchy Process to create a performance indicator framework for the evaluation of sustainable tourism in the Taiwan coastal area. The criteria covered in the study were environment and ecology, economy and development, society and culture, value creation in tourism, management and policy, and climate. Diaz and Rodriguez (2016) conducted a statistical study to determine the performance and sustainability factors of tourism destinations in Spain. Competitiveness, quality, tourist satisfaction, expenses, profit sector, the annual occupancy rate, tourists' extra expenditures, employee satisfaction, the effect on the economy, stability and employment growth, cooperation among agencies, customer loyalty, emotional experience, and image were indicated in terms of performance and customer criteria to measure tourism destination. 
Han et al. (2018) used statistical methods in their study on the role of wellness spa tourism performance in establishing destination loyalty in Thailand. Performance factors emerged as the quality of treatment, variety of service options, therapist and assistant personnel and resources. İlban and Yildirım (2017) analyzed the tourism performance of 15 countries, which are the most popular global tourism destinations, using TOPSIS method in order to determine tourism activities in the world's best tourism destinations. In their studies, they determined international tourism expenditures, revenues, arrival numbers, and departure numbers as the main criteria. Seraphin et al. (2018) utilized a multi-criteria decision-making method for the selection of destinations in Cuba based on tourism performance in their study. They cited criteria for the destination as supporting factors and resources, policy planning and development, management, as well as qualifier and explanatory factors.

Lakicevic and Durkalic (2018) used PROMETHEE, one of the multicriteria decision-making methods, to measure tourism market performance in European Union countries. The number of foreign tourists, the number of domestic tourists, the number of hotels, pollution, population density, railway lines, airline terminals, and cost of living were revealed as performance criteria. Niavis and Tsiotas (2019) used data envelopment analysis to assess the tourism performance of Mediterranean coastal destinations in terms of effectiveness and efficiency. In their study, performance dimensions, location, bed, shore, and labor capacity as input and total demand as output were determined.

As highlighted in the literature, tourism performance criteria are handled together with sustainability factors under the umbrella of market potential and destination (Wadongo et al., 2010; Pnevmatikoudi \& Stavrinoudis, 2016; Ribeiro et al., 2019). This shows that there is a gap in terms of health tourism. As a result of a detailed literature review and expert opinions, the criteria for measuring health tourism performance, considered as a gap in the related literature, were derived. These criteria are listed as follows: service quality, customer satisfaction, safety, innovation, resource utilization, social perspective, time, financial performance, price, supplier performance, flexibility, environmental perspective, employee satisfaction, and competition.

- Service Quality: Maintaining the 5-star hotel classification, evaluating the attitudes and behaviors of the guests, evaluating the services such as recreation for the guests, 
- Customer Satisfaction: Customers' satisfaction with the service they receive,

- Security: Degree of the building ensures personal safety,

- Innovation: Number of innovative product and service,

- Resource Utilization (machinery, equipment, labor, etc.): Frequency of equipment failure,

- Social Perspective: Number of community service projects, number of corporate sponsorships,

- Time: Meeting customer needs on time, delivering products and services of guests on time,

- Financial Performance: Net profit, gross profit, turnover, total income, food and beverage sales,

- Price: Average room rate per day,

- Supplier Performance (Agent Performance): Timely delivery of hotel suppliers, meeting standard purchase specifications,

- Flexibility: Adapting to guests' wishes and needs,

- Environmental Perspective: Number of environmental projects undertaken by the hotel, participation in environmental protection programs,

- Employee Satisfaction: Employee job satisfaction,

- Competition: Monitoring competitors' performance by questioning market share, growth in sales, and occupancy levels.

Based on the literature reviewed above, it was concluded that the Multi-Criteria Decision-Making Method that would relate to the tourism performance criteria could be DEMATEL and that fuzzy logic should be used to eliminate uncertainty that would arise from expert opinions. In the original DEMATEL, the relationship between decision factors is evaluated through clear values, thereby building a structural model. However, in many practical applications, people's judgments are often unclear, and the exact value is not enough to estimate the ambiguous interdependence between standards (Sheng-Li et al., 2018). It is important to use a measurement method that will allow critical evaluation beyond a structural evaluation, especially in a study on performance. Therefore, the concept of fuzzy sets has been applied to the DEMATEL method by many researchers. 


\section{METHODOLOGY}

DEMATEL is a multi-criteria decision-making technique that establishes a causality relationship between complex factors in a structural model, enabling classification through the interactions of these factors (Tzeng et al., 2007; Wu \& Lee, 2007). The Decision-Making Trial and Evaluation Laboratory Method (DEMATEL) method was first developed by the Geneva Battelle Memorial Institute in Geneva between 1972 and 1976 (Tzeng et al., 2007; Wu, 2008). DEMATEL method turns the relationship into an understandable structural model to analyze interdependent relationships between factors in a complex system and to rank them in determining the scope of long-term strategic decision making and improvement. With DEMATEL, factors can be listed according to their importance, and the level of influence between them can be determined. Recently, researchers have indicated suitability of combining with fuzzy theory-based approaches in order to eliminate the complexity of meaning created by the quantitative expression of the degree of interaction between factors (Liu et al., 2012; Baykaşoğlu et al., 2013; Organ, 2013; Altuntaş \& Yılmaz, 2016; GökKısa \& Perçin, 2017; Nilashi et al., 2019). Fuzzy theory is very useful for dealing with the ambiguity of human thought and language when making decisions. Decision-makers tend to make assessments based on their experience and knowledge and express their ideas often in linguistic language terms. Therefore, the need to use fuzzy logic in decisionmaking problems became apparent (Kaufmann \& Gupta, 1991). The Fuzzy DEMATEL method integrates classical DEMATEL approach with the Fuzzy Set Theory (Zadeh, 1965) and develops solutions based on fuzzy numbers. Thus, the relationship between relative concepts and criteria based on linguistic descriptions can be determined instead of crisp numerical descriptions. The procedure of the Fuzzy DEMATEL technique is listed below ( $\mathrm{Lin} \& \mathrm{Wu}, 2008)$.

\section{Step 1: Set the decision goal and set up a committee}

The first step in decision-making process is selection of the participants who will form an expert committee in which the intended targets are determined, and the necessary information about the problem is collected.

\section{Step 2: Develop the evaluation criteria and design the fuzzy linguistic scale}

In this step, the criteria must be determined for evaluation. Significant relationships between these factors should be established by experts to 
determine cause and effect factors. After these relationships are established, pairwise comparisons between the criteria must be made. In comparison, fuzzy scale applied to determine to what extent one factor affects another was used. According to this scale, there are five linguistic terms, which are defined as "very high, high, low, very low, no," as one factor affects another factor as linguistic value. Triangular fuzzy numbers corresponding to these linguistic terms are presented in Table 1 and Figure 1 (Li, 1999).

Table 1. Fuzzy Linguistic Scale

\begin{tabular}{cc}
\hline Linguistic Terms & Fuzzy Values \\
\hline Very high influence $(V H)$ & $(0.75 ; 1.00 ; 1.00)$ \\
High influence $(H)$ & $(0.50 ; 0.75 ; 1.00)$ \\
Low influence $(L)$ & $(0.25 ; 0.50 ; 0.75)$ \\
Very low influence $(V L)$ & $(0.00 ; 0.25 ; 0.50)$ \\
No influence $(N o)$ & $(0.00 ; 0.00 ; 0.25)$ \\
\hline
\end{tabular}

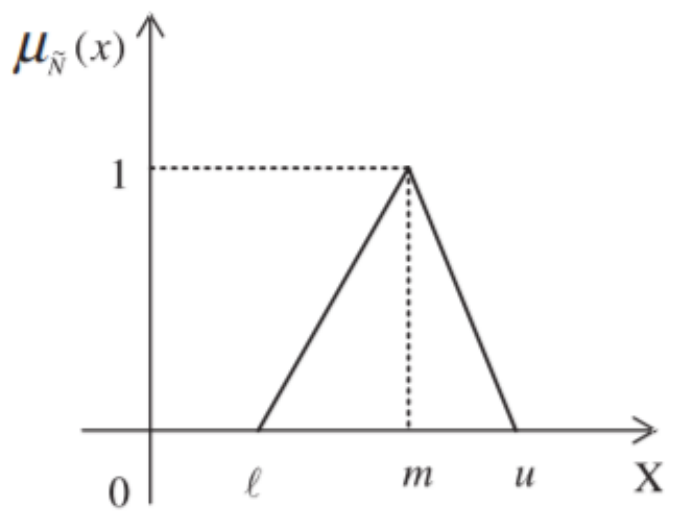

Figure 1. Triangular Fuzzy Numbers

\section{Step 3: Create a direct relationship matrix with data acquired from decision-makers}

In this step, the pairwise comparison matrix is created using the linguistic scale where decision-makers determine the level of relations between the specified $C=\{C 1, C 2 \ldots . . C n\}$ n number of criteria. The decision matrix $(p)$ as many as the number of experts in the decision group is acquired. $\tilde{Z}$ is obtained as a fuzzy direct relation matrix. The $\tilde{z}_{i j}$ value indicates the degree to which $i$ criterion influences the $j$ criterion. 


$$
\begin{aligned}
& \tilde{Z}^{(k)}=\left[\begin{array}{ccc}
0 & \cdots & \tilde{z}_{1 n}^{k} \\
\vdots & \ddots & \vdots \\
\tilde{z}_{n 1}^{k} & \cdots & 0
\end{array}\right] ; k=1,2,3 \ldots, p, \\
& \tilde{z}_{i j}=\left(l_{i j}, m_{i j}, u_{i j}\right)
\end{aligned}
$$

\section{Step 4: Acquire the normalized direct-relation fuzzy matrix}

Following equation formulas obtain the normalized direct relation matrix. The values of $u$ in each criterion representing the last of the triangular fuzzy numbers are collected in columns, and a single value is obtained for each column. The biggest of these obtained values is selected, and this value is defined as $r$.

$$
r^{(k)}=\max _{1 \leq i \leq n}\left(\sum_{j=1}^{n} u_{i j}^{k}\right)
$$

Then the whole matrix is divided into $r$, and a normalized direct relation matrix is obtained. The normalized direct relation matrix is denoted by $\tilde{X} . \tilde{X}$ is obtained from the average of the normalized direct relationship matrices of all participants.

$$
\begin{aligned}
& \tilde{X}^{(k)}=\left[\begin{array}{ccc}
\tilde{x}_{11}^{(k)} & \cdots & \tilde{x}_{1 n}^{k} \\
\vdots & \ddots & \vdots \\
\tilde{x}_{n 1}^{(k)} & \cdots & \tilde{x}_{n n}^{k}
\end{array}\right] ; k=1,2,3 \ldots, p, \\
& \tilde{X}_{i j}^{(k)}=\frac{\tilde{z}_{i j}^{(k)}}{r^{(k)}}=\left(\frac{l_{i j}}{r^{(k)}}, \frac{m_{i j}}{\left.r^{(k)}\right)}, \frac{u_{i j}}{r^{(k)}}\right) \\
& \tilde{X}=\left(\frac{\tilde{X}^{(1)}+\tilde{X}^{(2)}+\cdots+\tilde{X}^{(p)}}{p}\right)
\end{aligned}
$$

\section{Step 5: Establish the structural model showing the importance and cause- effect relationships between the criteria}

After the normalized relationship matrix is obtained, the $\tilde{T}$ total relationship matrix is created using the equations below. After the total relation matrix $\widetilde{T}$ is obtained, $\widetilde{D}_{i}+\widetilde{R}_{i}$ and $\widetilde{D}_{i}-\widetilde{R}_{i}$ values are calculated to give the sum of the row elements in the matrix $\widetilde{D}_{i}$, and the sum of the line elements in the matrix is $\tilde{R}_{i}$.

$$
\tilde{T}=\lim _{k \rightarrow \infty}\left(X+X^{2}+\cdots+X^{k}=X(1-X)^{-1}\right.
$$




$$
\widetilde{D}_{i}=\sum_{j=1}^{n} t_{i j}(i=1,2, \ldots, n) \widetilde{R}_{i}=\sum_{i=1}^{n} t_{i j}(j=1,2, \ldots, n)
$$

Clarification is applied to turn the obtained $\mathrm{D}+\mathrm{R}$ and $\mathrm{D}-\mathrm{R}$ values into a single value. The abbreviation "def" on the formulas means the word "defuzzifying," which means clarification. Clarification is conducted with the formula mentioned below.

$D_{i}^{d e f}+R_{i}^{d e f}=1 / 4(1+2 m+u)$

$D_{i}^{d e f}-R_{i}^{d e f}=1 / 4(1+2 m+u)$

Using the $D+R$ and $D-R$ values obtained after the clarification process, the effect and relationship level of each criterion with other criteria are determined. In the causal relationship matrix, $\mathrm{D}+\mathrm{R}$ is on the horizontal axis, and $D-R$ is on the vertical axis. The criteria in which the $D-R$ value is negative have a lower effect and priority over other criteria and are referred to as the receiver criteria. $D+R$ values indicate the level of the relationship between the criteria. Criteria with high $D+R$ value are more correlated with the other criteria. Criteria with low $\mathrm{D}+\mathrm{R}$ value are less correlated with the other criteria.

\section{Step 6: Determination of weights}

The weights of the criteria are determined by using the following formula:

$$
\begin{aligned}
& w_{i}=\sqrt{\left(D_{i}^{d e f}+R_{i}^{d e f}\right)^{2}+\left(D_{i}^{d e f}-R_{i}^{d e f}\right)^{2}} \\
& W_{i}=\frac{w_{i}}{\sum_{i=1}^{n} w_{i}}
\end{aligned}
$$




\section{FINDINGS}

Tourism is an important sector in Antalya as well as Turkey that has developed and expanded rapidly in recent years and is used as a tool for regional and national development, both as well as the growth potential of the sector and many other industries (Çımat \& Bahar, 2003). In the implementation of this study, the evaluation of criteria to determine performance of health tourism was carried out. Aim of the study is to determine the cause and effect criteria by revealing the extent of the relationship between the fuzzy DEMATEL method and performance criteria to address the complexity. During the implementation, evaluations of an expert group of decision-makers in health tourism of the tourism sector were taken as a basis. Thus, the first step of setting the study goal and determining the decision-makers is completed.

Table 2. Factors Influencing Health Tourism Performance

\begin{tabular}{l}
\hline Criteria \\
\hline C1 Service Quality \\
C2 Customer Satisfaction \\
C3 Safety \\
C4 Innovation \\
C5 Resource Utilization \\
C6 Social Perspective \\
C7 Time \\
C8 Financial Performance \\
C9 Price \\
C10 Supplier Performance \\
C11 Flexibility \\
C12 Environmental Perspective \\
C13 Employee Satisfaction \\
C14 Competition
\end{tabular}

In the second step, criteria were acquired from the literature and reviewed by a team of experts in order to apply them to health tourism, and necessary additions were made. Study was held with 3 experts within the scope of the research. One of the experts interviewed has been a manager in the tourism sector for many years. The second expert is a manager in a medical tourism company. The third is a professor who works in the field of tourism. All the criteria obtained are seen in Table 2. The relationships among criteria were prepared as Table 2 according to the linguistic evaluations of decision-makers according to linguistic terms in Table 1. The assessment of the expert group was combined and evaluated. In the Table 3 , mutual interaction is presented in the light of the opinions of the expert 
group. For example, the effect size of $\mathrm{C} 1$ criterion on $\mathrm{C} 2$ is presented in the $\mathrm{C} 2-\mathrm{C} 1$ column, and the effect of $\mathrm{C} 2$ criterion on $\mathrm{C} 1$ is presented in the $\mathrm{C} 1$ C2 column.

Table 3. Comparing the Criteria with Linguistic Terms of Decision-Makers

\begin{tabular}{|c|c|c|c|c|c|c|c|c|c|c|c|c|c|c|}
\hline & $\mathrm{C} 1$ & C2 & $\mathrm{C} 3$ & C4 & C5 & C6 & C7 & C8 & C9 & C10 & C11 & $\mathrm{C} 12$ & $\mathrm{C} 13$ & C14 \\
\hline $\mathrm{C} 1$ & 0 & 4 & 3 & 3 & 4 & 3 & 5 & 5 & 5 & 3 & 4 & 2 & 2 & 4 \\
\hline$C 2$ & 5 & 0 & 3 & 4 & 5 & 4 & 5 & 5 & 5 & 4 & 5 & 2 & 2 & 4 \\
\hline 53 & 2 & 2 & 0 & 2 & 3 & 1 & 3 & 3 & 3 & 3 & 3 & 1 & 1 & 3 \\
\hline C4 & 2 & 3 & 2 & 0 & 2 & 1 & 2 & 2 & 3 & 2 & 2 & 2 & 1 & 3 \\
\hline C5 & 3 & 3 & 3 & 2 & 0 & 1 & 2 & 3 & 2 & 2 & 3 & 1 & 2 & 4 \\
\hline C6 & 2 & 2 & 1 & 1 & 1 & 0 & 1 & 2 & 2 & 2 & 3 & 1 & 2 & 3 \\
\hline C7 & 4 & 4 & 4 & 3 & 2 & 1 & 0 & 3 & 4 & 3 & 5 & 1 & 2 & 5 \\
\hline C8 & 5 & 5 & 3 & 5 & 2 & 1 & 4 & 0 & 5 & 4 & 4 & 1 & 2 & 4 \\
\hline C9 & 5 & 3 & 2 & 5 & 4 & 2 & 5 & 5 & 0 & 4 & 5 & 1 & 3 & 5 \\
\hline C10 & 3 & 4 & 2 & 1 & 2 & 1 & 2 & 2 & 1 & 0 & 3 & 1 & 2 & 3 \\
\hline C11 & 4 & 3 & 3 & 3 & 3 & 3 & 4 & 5 & 5 & 5 & 0 & 2 & 2 & 5 \\
\hline C12 & 2 & 2 & 1 & 2 & 1 & 1 & 2 & 1 & 2 & 2 & 2 & 0 & 2 & 3 \\
\hline $\mathrm{C} 13$ & 1 & 2 & 1 & 1 & 1 & 2 & 1 & 1 & 1 & 2 & 1 & 2 & 0 & 1 \\
\hline $\mathrm{C} 14$ & 4 & 4 & 4 & 2 & 3 & 1 & 4 & 4 & 5 & 2 & 5 & 1 & 1 & 0 \\
\hline
\end{tabular}

(5: very high, 4 : high, 3 : low, 2 : very low, 1 : no)

In the second step, by using triangular fuzzy number values corresponding to linguistic terms in Table 4, a direct relation matrix is obtained. 
Table 4. Direct Relationship Matrix

$\begin{array}{ccccccc}\mathrm{C} 1 & \mathrm{C} 2 & \mathrm{C} 3 & \mathrm{C} 4 & \mathrm{C} 5 & \mathrm{C} 6 & \mathrm{C} 7 \\ \mathrm{C} 8 & \mathrm{C} 9 & \mathrm{C} 10 & \mathrm{C} 11 & \mathrm{C} 12 & \mathrm{C} 13 & \mathrm{C} 14\end{array}$

\begin{tabular}{|c|c|c|c|c|c|c|}
\hline$(0,0,0)$ & $(0.5,0.75,1)$ & $(0.25,0.5,0.75)$ & $(0.25,0.5,0.75)$ & $(0.5,0.75,1)$ & $(0.25,0.5,0.75)$ & $(0.75,1,1)$ \\
\hline$(0.75,1,1)$ & $(0.75,1,1)$ & $(0.25,0.5,0.75)$ & $(0.5,0.75,1)$ & $(0,0,25,05)$ & $(0,0,25,05)$ & $(0.5,0.75,1)$ \\
\hline$(0.75,1,1)$ & $(0,0,0)$ & $(0.25,0.5,0.75)$ & $(0.5,0.75,1)$ & $(0.75,1,1)$ & $(0.5,0.75,1)$ & $(0.75,1,1)$ \\
\hline$(0.75,1,1)$ & $(0.75,1,1)$ & $(0.5,0.75,1)$ & $(0.75,1,1)$ & $(0,0,25,05)$ & $(0,0,25,05)$ & $(0.5,0.75,1)$ \\
\hline$(0,0,25,05)$ & $(0,0,25,05)$ & $(0,0,0)$ & $(0,0,25,05)$ & $(0.25,0.5,0.75)$ & $(0,0,025)$ & $(0.25,0.5,0.75)$ \\
\hline$(0.25,0.5,0.75)$ & $(0.25,0.5,0.75)$ & $(0.25,0.5,0.75)$ & $(0.25,0.5,0.75)$ & $(0,0,025)$ & $(0,0,025)$ & $(0.25,0.5,0.75)$ \\
\hline$(0,0,25,05)$ & $(0.25,0.5,0.75)$ & $(0,0,25,05)$ & $(0,0,0)$ & $(0,0,25,05)$ & $(0,0,025)$ & $(0,0,25,05)$ \\
\hline$(0,0,25,05)$ & $(0.25,0.5,0.75)$ & $(0,0,25,05)$ & $(0,0,25,05)$ & $(0,0,25,05)$ & $(0,0,025)$ & $(0.25,0.5,0.75)$ \\
\hline$(0.25,0.5,0.75)$ & $(0.25,0.5,0.75)$ & $(0.25,0.5,0.75)$ & $(0,0,25,05)$ & $(0,0,0)$ & $(0,0,025)$ & $(0,0,25,05)$ \\
\hline$(0.25,0.5,0.75)$ & $(0,0,25,05)$ & $(0,0,25,05)$ & $(0.25,0.5,0.75)$ & $(0,0,025)$ & $(0,0,25,05)$ & $(0.5,0.75,1)$ \\
\hline$(0,0,25,05)$ & $(0,0,25,05)$ & $(0,0,025)$ & $(0,0,025)$ & $(0,0,025)$ & $(0,0,0)$ & $(0,0,025)$ \\
\hline$(0,0,25,05)$ & $(0,0,25,05)$ & $(0,0,25,05)$ & $(0.25,0.5,0.75)$ & $(0,0,025)$ & $(0,0,25,05)$ & $(0.25,0.5,0.75)$ \\
\hline$(0.5,0.75,1)$ & $(0.5,0.75,1)$ & $(0.5,0.75,1)$ & $(0.25,0.5,0.75)$ & $(0,0,25,05)$ & $(0,0,025)$ & $(0,0,0)$ \\
\hline$(0.25,0.5,0.75)$ & $(0.5,0.75,1)$ & $(0.25,0.5,0.75)$ & $(0.75,1,1)$ & $(0,0,025)$ & $(0,0,25,05)$ & $(0.75,1,1)$ \\
\hline$(0.75,1,1)$ & $(0.75,1,1)$ & $(0.25,0.5,0.75)$ & $(0.75,1,1)$ & $(0,0,25,05)$ & $(0,0,025)$ & $(0.5,0.75,1)$ \\
\hline$(0,0,0)$ & $(0.75,1,1)$ & $(0.5,0.75,1)$ & $(0.5,0.75,1)$ & $(0,0,025)$ & $(0,0,25,05)$ & $(0.5,0.75,1)$ \\
\hline$(0.75,1,1)$ & $(0.25,0.5,0.75)$ & $(0,0,25,05)$ & $(0.75,1,1)$ & $(0.5,0.75,1)$ & $(0,0,25,05)$ & $(0.75,1,1)$ \\
\hline$(0.75,1,1)$ & $(0,0,0)$ & $(0.5,0.75,1)$ & $(0.75,1,1)$ & $(0,0,025)$ & $(0.25,0.5,0.75)$ & $(0.75,1,1)$ \\
\hline$(0.25,0.5,0.75)$ & $(0.5,0.75,1)$ & $(0,0,25,05)$ & $(0,0,025)$ & $(0,0,25,05)$ & $(0,0,025)$ & $(0,0,25,05)$ \\
\hline$(0,0,25,05)$ & $(0,0,025)$ & $(0,0,0)$ & $(0.25,0.5,0.75)$ & $(0,0,025)$ & $(0,0,25,05)$ & $(0.25,0.5,0.75)$ \\
\hline$(0.5,0.75,1)$ & $(0.25,0.5,0.75)$ & $(0.25,0.5,0.75)$ & $(0.25,0.5,0.75)$ & $(0.25,0.5,0.75)$ & $(0.25,0.5,0.75)$ & $(0.5,0.75,1)$ \\
\hline$(0.75,1,1)$ & $(0.75,1,1)$ & $(0.75,1,1)$ & $(0,0,0)$ & $(0,0,25,05)$ & $(0,0,25,05)$ & $(0.75,1,1)$ \\
\hline$(0,0,25,05)$ & $(0,0,25,05)$ & $(0,0,025)$ & $(0,0,25,05)$ & $(0,0,025)$ & $(0,0,025)$ & $(0,0,25,05)$ \\
\hline$(0,0,025)$ & $(0,0,25,05)$ & $(0,0,25,05)$ & $(0,0,25,05)$ & $(0,0,0)$ & $(0,0,25,05)$ & $(0.25,0.5,0.75)$ \\
\hline$(0,0,025)$ & $(0,0,25,05)$ & $(0,0,025)$ & $(0,0,025)$ & $(0,0,025)$ & $(0,0,25,05)$ & $(0,0,025)$ \\
\hline$(0,0,025)$ & $(0,0,025)$ & $(0,0,25,05)$ & $(0,0,025)$ & $(0,0,25,05)$ & $(0,0,0)$ & $(0,0,025)$ \\
\hline$(0.5,0.75,1)$ & $(0.5,0.75,1)$ & $(0.5,0.75,1)$ & $(0,0,25,05)$ & $(0.25,0.5,0.75)$ & $(0,0,025)$ & $(0.5,0.75,1)$ \\
\hline$(0.5,0.75,1)$ & $(0.75,1,1)$ & $(0,0,25,05)$ & $(0.75,1,1)$ & $(0,0,025)$ & $(0,0,025)$ & $(0,0,0)$ \\
\hline
\end{tabular}


In the third step, using equations 1 and 2, normalized direct relationship matrix is prepared. The data is as seen in Table 5 as the matrix.

Table 5. Normalized Direct Relationship Matrix

$\mathrm{L}$

\begin{tabular}{|c|c|c|c|}
\hline \multirow[t]{2}{*}{$\mathrm{C} 1$} & $\begin{array}{l}(0.000,0.068,0.000,0.000,0.000 .023,0,0.045 \\
0,068,0.068,0,023,0.045,0.000,0.000,0.045)\end{array}$ & $\begin{array}{l}0.000,0.091,0.023,0.023,0.045,0.023,0.068 \\
0.091,0,045,0.068,0,023,0.023,0.000,0.068)\end{array}$ & $\begin{array}{l}(0.000,0.091,0.045,0.045,0.045,0.045,0.091, \\
0.091,0.091,0.068,0.091,0.045,0.023,0.091)\end{array}$ \\
\hline & $(0.045,0.000,0.000,0.023,0.023,0.000,0.045$ & $(0.068,0.000,0.023,0.045,0.045,0.023,0.068$, & $(0.091,0.000,0.045,0.068,0.068,0.045,0.091$ \\
\hline \multirow[t]{2}{*}{$\mathrm{C} 2$} & $0.068,0.023,0.045,0.023,0.000,0.000,0.045)$ & $0.091,0.045,0.068,0.045,0.023,0.023,0.068)$ & $0.091,0.068,0.091,0.068,0.045,0.045,0.091)$ \\
\hline & $(0.023,0.023,0.000,0.000,0.023,0.000,0.045$ & $(0.045,0.045,0.000,0.023,0.045,0.000,0.068$ & $(0.068,0.068,0.000,0.045,0.068,0.023,0.091$, \\
\hline \multirow[t]{2}{*}{ C3 } & $0.000,0.000,0.000,0.023,0.000,0.000,0.045)$ & $0.023,0.023,0.023,0.045,0.000,0.000,0.068)$ & $0.045,0.045,0.045,0.068,0.023,0.023,0.091)$ \\
\hline & $(0.023,0.045,0.000,0.000,0.000,0.000,0.023$ & $(0.045,0.068,0.023,0.000,0.023,0.000,0.045$ & $(0.068,0.091,0.045,0.000,0.045,0.023,0.068$ \\
\hline \multirow[t]{2}{*}{$\mathrm{C} 4$} & $0.068,0.068,0.000,0.023,0.000,0.000,0.000)$ & $0.091,0.091,0.000,0.045,0.023,0.000,0.0023)$ & $0.091,0.091,0.023,0.068,0.045,0.023,0.045)$ \\
\hline & $(0.045,0.068,0.023,0.000,0.000,0.000,0.000$ & $(0.068,0.091,0.045,0.023,0.000,0.000,0.023$, & $(0.091,0.091,0.068,0.045,0.000,0.023,0.045$ \\
\hline \multirow[t]{2}{*}{ C5 } & $0.000,0.045,0.000,0.023,0.000,0.000,0.023)$ & $0.023,0.068,0.023,0.045,0.000,0.000,0.045)$, & $0.045,0.091,0.045,0.068,0.023,0.023,0.068)$ \\
\hline & $(0.023,0.045,0.000,0.000,0.023,0.000,0.000$ & $(0.045,0.068,0.000,0.000,0.045,0.000,0.000$ & $(0.068,0.091,0.023,0.023,0.068,0.000,0.023$, \\
\hline \multirow[t]{2}{*}{ C6 } & $0.000,0.000,0.000,0.023,0.000,0.000,0.000)$ & $0.000,0.023,0.000,0.045,0.000,0.023,0.000)$, & $0.023,0.045,0.023,0.068,0.023,0.045,0.023)$ \\
\hline & $(0.068,0.068,0.023,0.000,0.000,0.000,0.000$ & $(0.091,0.091,0.045,0.023,0.023,0.000,0.000$ & $(0.091,0.091,0.068,0.045,0.045,0.023,0.000$ \\
\hline \multirow[t]{2}{*}{$\mathrm{C} 7$} & $0.045,0.068,0.045,0.000,0.000,0.000,0.045)$ & $0.068,0.091,0.023,0.068,0.023,0.000,0.068)$ & $0.091,0.091,0.045,0.091,0.045,0.000,0.0091)$ \\
\hline & $(0.068,0.068,0.023,0.023,0.000,0.023,0.000$, & $(0.091,0.091,0.045,0.023,0.045,0.023,0.045$ & $(0.091,0.091,0.068,0.045,0.068,0.045,0.068$ \\
\hline \multirow[t]{2}{*}{$\mathrm{C} 8$} & $0.068,0.000,0.068,0.000,0.000,0.000,0.045)$ & $0.000,0.091,0.023,0.091,0.000,0.000,0.068)$ & $0.000,0.091,0.045,0.091,0.023,0.023,0.091)$ \\
\hline & $(0.068,0.068,0.023,0.023,0.000,0.000,0.045$, & $(0.091,0.091,0.045,0.045,0.023,0.023,0.068$ & $(0.091,0.091,0.068,0.068,0.045,0.045,0.091$, \\
\hline \multirow[t]{2}{*}{ C9 } & $0.068,0.000,0.000,0.068,0.000,0.0000 .068)$ & $0.091,0.000,0.000,0.091,0.023,0.000,0.091)$ & $0.091,0.000,0.023,0.091,0.045,0.023,0.091)$ \\
\hline & $(0.023,0.045,0.023,0.000,0.000,0.000,0.023$ & $(0.045,0.068,0.045,0.023,0.023,0.023,0.045$ & $(0.068,0.091,0.068,0.045,0.045,0.045,0.068$ \\
\hline \multirow[t]{2}{*}{$\mathrm{C} 10$} & $0.045,0.045,0.000,0.068,0.000,0.000,0.000)$ & $0.068,0.068,0.091,0.023,0.000,0.000,0.000)$ & $0.091,0.091,0.000,0.091,0.045,0.045,0.045)$ \\
\hline & $(0.045,0.068,0.023,0.000,0.000,0.023,0.068$ & $(0.068,0.091,0.045,0.023,0.023,0.045,0.091$ & $(0.091,0.091,0.068,0.045,0.045,0.068,0.091$ \\
\hline \multirow[t]{2}{*}{$\mathrm{C} 11$} & $0.045,0.068,0.023,0.000,0.000,0.000,0.068$ & $0.068,0.091,0.045,0.000,0.023,0.000,0.091)$ & $0.091,0.091,0.068,0.000,0.045,0.023,0.091)$ \\
\hline & $(0.000,0.000,0.000,0.000,0.000,0.000,0.000$ & $(0.023,0.023,0.000,0.023,0.000,0.000,0.000$ & $(0.045,0.045,0.023,0.045,0.023,0.023,0.023$ \\
\hline \multirow[t]{2}{*}{$\mathrm{C} 12$} & $0.000,0.000,0.000,0.000,0.000,0.000,0.000)$, & $0.000,0.000,0.023,0.023,0.000,0.023,0.000)$ & $0.023,0.023,0.045,0.045,0.000,0.023,0.045)$ \\
\hline & $(0.000,0.000,0.000,0.000,0.000,0.000,0.000$ & $(0.023,0.023,0.000,0.000,0.023,0.023,0.023$ & $(0.045,0.045,0.023,0.023,0.045,0.045,0.045$ \\
\hline \multirow[t]{2}{*}{$\mathrm{C} 13$} & $0,023,0.000,0.000,0.000,0.000,0.000,0.000)$ & $0.045,0.023,0.023,0.023,0.023,0.000,0.000)$ & $0.068,0.045,0.045,0.045,0.045,0.000,0.0023)$ \\
\hline & $(0.045,0.045,0.023,0.023,0.045,0.023,0.068$ & $(0.068,0.068,0.045,0.045,0.068,0.045,0.091$, & $(0.091,0.091,0.068,0.068,0.091,0.068,0.091$, \\
\hline $\mathrm{C} 14$ & $0.045,0.068,0.023,0.023,0.023,0.000,0.000)$ & $0.068,0.091,0.45,0.091,0.045,0.000,0.000)$ & $0.091,0.091,0.068,0.091,0.068,0.023,0.000)$ \\
\hline
\end{tabular}




\section{In the fourth step, total relation matrix is obtained with help of equation 3 , as seen in Table 6 .}

\section{Table 6. Total Relation Matrix}

$\mathrm{L}$

\begin{tabular}{|c|c|c|c|}
\hline \multirow[t]{2}{*}{$\mathrm{C} 1$} & $\begin{array}{l}(1.031,0.100,0.011,0.006,0.031,0.003,0.069, \\
0.095,0.097,0.031,0.070,0.002,0.000,0.071)\end{array}$ & $\begin{array}{l}(1.107,0.205,0.079,0.70,0.101,0.056,0.156, \\
0.187,0.194,0.92,0.168,0.053,0.009,0.159)\end{array}$ & $\begin{array}{c}(1.329,0.428,0.276,0.253,0.275,0.221,0.385 \\
0.395,0.4,0.285,0.404,0.217,0.137,0.385)\end{array}$ \\
\hline & $(0.069,1.031,0.009,0.026,0.039,0.003,0.064$ & $(0.162,1.112,0.75,0.86,0.97,0.053,0.148$ & $(0.423,1.356,0.284,0.279,0.302,0.226,0.394$ \\
\hline \multirow[t]{2}{*}{$\mathrm{C} 2$} & $0.091,0.051,0.052,0.046,0.001,0.000,0.065)$ & $0.180,0.147,0.110,0.141,0.151,0.030,0.149)$ & $0.406,0.391,0.307,0.395,0.223,0.161,0.393)$ \\
\hline & $(0.036,0.038,1.005,0.002,0.027,0.002,0.056$ & $(0.111,0.121,1.037,0.53,0.81,0.021,0.125$ & $(0.337,0.350,1.194,0.217,0.256,0.169,0.334$ \\
\hline \multirow[t]{2}{*}{$\mathrm{C} 3$} & $0.013,0.016,0.005,0.032,0.001,0.000,0.056)$ & $0.088,0.095,0.055,0.110,0.021,0.005,0.126)$ & $0.303,0.307,0.223,0.329,0.167,0.116,0.334)$ \\
\hline & $(0.044,0.068,0.006,0.004,0.006,0.001,0.038$ & $(0.123,0.153,0.064,1.035,0.064,0.024,0.112$ & $(0.342,0.374,0.209,1.177,0.238,0.171,0.138$ \\
\hline \multirow[t]{2}{*}{$\mathrm{C} 4$} & $0.087,0.086,0.005,0.041,0.000,0000,0.020)$ & $0.162,0.166,0.036,0.120,0.044,0.006,0.095)$ & $0.347,0.350,0.205,0.333,0.189,0.118,0.299)$ \\
\hline & $(0.060,0.085,0.027,0.004,1.006,0.002,0.016$ & $(0.139,0.170,0.084,0.057,1.042,0.024,0.091$ & $(0.365,0.378,0.263,0.223,1.198,0.174,0.303$ \\
\hline \multirow[t]{2}{*}{ C5 } & $0.019,0.060,0.007,0.036,0.001,0.000,0.039)$ & $0.098,0.141,0.059,0.116,0.023,0.006,0.116)$ & $0.311,0.354,0.229,0.337,0.171,0.120,0.323)$ \\
\hline & $(0.030,0.053,0.002,0.002,0.025,0.001,0.007$ & ()0.081,0.109,0.020,0.017,0.065,1.013,0.034, & $(0.270,0.300,0.167 .0 .153,0.209,1.111,0.211$, \\
\hline \multirow[t]{2}{*}{ C6 } & $0.008,0.008,0.004,0.028,0.000,0.000,0.008)$ & $0.039,0.061,0.021,0.079,0.11,0.026,0.036)$ & $0.218,0.241,0.160,0.263,0.131,0.117,0.211))$ \\
\hline & $(0.094,0.098,0.031,0.006,0.010,0.003,1.026$ & $(0.185,0.198,0.097,0.068,0.077,0.033,1.090$ & $(0.401,0.415,0.288,0.246,0.266,0.193,1.292$ \\
\hline \multirow[t]{2}{*}{ C7 } & $0.073,0.094,0.010,0.068,0.002,0.000,0.071)$ & $0.163,0.188,0.070,0.162,0.052,0.008,0.157)$ & $0.384,0.388,0.252,0.392,0.210,0.111,0.376)$ \\
\hline & $(0.095,0.100,0.031,0.006,0.032,0.004,0.049$ & $(0.189,0.203,0.099,0.069,0.101,0.056,0.137$ & $(0.407,0.422,0.292,0.249,0.291,0.217,0.360$ \\
\hline \multirow[t]{2}{*}{$\mathrm{C} 8$} & $1.030,0.096,0.010,0.090,0.002,0.000,0.073)$ & $1.102,0.192,0.072,0.186,0.031,0.008,0.160)$ & $1.305,0.394,0.256,0.397,0.193,0.134,0.380)$ \\
\hline & $(0.098,0.103,0.032,0.028,0.012,0.004,0.074$ & $(0.194,0.208,0.101,0.092,0.084,0.057,0.162$ & $(0.411,0.426,0.294,0.272,0.274,0.219,0.384$ \\
\hline \multirow[t]{2}{*}{ C9 } & $0.099,1.037,0.011,0.092,0.002,0.000,0.0096)$ & $0.191,1.115,0.054,0.191,0.054,0.008,0.184)$ & $0.393,1.314,0.238,0.401,0.216,0.135,0.384)$ \\
\hline & $(0.044,0.068,0.029,0.004,0.006,0.002,0.041$ & $(0.131,0.163,0.090,0.060,0.069,0.050,0.121$ & $(0.378,0.412,0.285,0.243,0.264,0.212,0.351$ \\
\hline \multirow[t]{2}{*}{$\mathrm{C} 10$} & $0.065,0.065,1,007,0.0084,0.000,0.000,0022)$ & $0.149,0.154,1.041,0.170,0.047,0.030,0.102)$ & $0.381,0.384,1.206,0.389,0.208,0.153,0.331)$ \\
\hline & $(0.077,0.0102,0.033,0.007,0.011,0.026,0.093$, & $(0.176,0.210,0.102,0.072,0.084,0.072,80.182$ & $(0.425,0.442,0.305,0.260,0.284,0.247,0.396$ \\
\hline \multirow[t]{2}{*}{$\mathrm{C} 11$} & $0.076,0.098,0.032,1.028,0.002,0.000,0.093)$ & $0.171,0.198,0.075,1.110,0.055,0.010,0.184)$ & $0.406,0.411,0.288,1.333,0.223,0.141,0.396)$ \\
\hline & $(0.000,0.0000 .000,0.000,0.000,0.000,0.000$ & $(0.040,0.043,0.010,0.030,0,010,0.007,0.018$ & $(0.203,0.211,0.135,0.145,0.135,0.109,0.169$ \\
\hline \multirow[t]{2}{*}{$\mathrm{C} 12$} & $0.000,1.000,0.0000,0.000,0.000,0.000,0.000)$ & $0.021,0.021,0.032,0.040,1.006,0.025,0.016)$ & $0.175,0.177,0.150,0.199,1.086,0.101,0.167)$ \\
\hline & $(0.002,0.002,0.001,0.000,0.001,0.000,0.001$ & $(0.059,0.064,0.019,0.016,0.042,0.034,0.052$ & $(0.245,0.254,0.164,0.150,0.185,0.152,0.226$ \\
\hline \multirow[t]{2}{*}{$\mathrm{C} 13$} & $0.023,0.002,0.000,0.002,0.000,0.000,0.002)$ & $0.077,0.059,0.039,0.058,0.032,1.004,0.0032)$ & $0.253,0.236,0.175,0.239,0.149,1.071,0.206)$ \\
\hline & $(0.075,0.081,0.032,0.027,0.053,0.024,0.089$ & $(0.181,0.196,0.106,0.095,0.127,0.79,0.185$ & $(0.452,0.470,0.324,0.297,0.342,0.260,0.419$, \\
\hline $\mathrm{C} 14$ & $0.074,0.097,0.030,0.049,0.023,0.000,1.027)$ & $0.175,0.205,0.096,0.198,0.077,0.010,0.104)$ & $0.430,0.437,0.305,0.441,0.257,0.151,1.336)$ \\
\hline
\end{tabular}


In the fifth step, the sum of the column elements D and the sum of row elements $R$ values are calculated in the matrix to form cause and effect group. The clarification process of these values was generated in Table 7, with the help of equation 5.

Table 7. Clarification of Criteria Values

\begin{tabular}{lcc}
\hline \multicolumn{1}{c}{ Criteria } & D+R & D-R \\
\hline C14 Competition & 6.421 & 0.219 \\
C11 Flexibility & 5.924 & 0.422 \\
C10 Supplier Performance & 5.547 & 0.149 \\
C4 Innovation & 4.949 & 0.309 \\
C5 Resource Utilization & 5.073 & 0.143 \\
C3 Safety & 4.938 & 0.074 \\
C6 Social Perspective & 4.023 & 0.058 \\
C2 Customer Satisfaction & 6.659 & -0.581 \\
C1 Service Quality & 6.443 & -0.306 \\
C8 Financial Performance & 6.202 & -0.14 \\
C7 Time & 6.114 & -0.164 \\
C9 Price & 6.411 & -0.19 \\
C13 Employee Satisfaction & 4.202 & -0.245 \\
C12 Environmental Perspective & 3.43 & -0.029 \\
\hline
\end{tabular}

Among the $\mathrm{D}+\mathrm{R}$ values that express priority and total impact among the criteria, it is observed that customer satisfaction, service quality, and competition criteria are more correlated with the other criteria. When D-R values that determine direction of the relationship between the criteria are analyzed, it was found out that positive safety, innovation, resource utilization, social perspective, supplier performance, and flexibility are cause criteria, while negative service quality, customer satisfaction, time, financial performance, price, environmental perspective, and employee satisfaction are effect criteria. Besides, criterion of flexibility, innovation, competition, and resource utilization was more influenced by D-R positive values with higher impact and priority, which are called as cause group. In this step, $D+R$ and $D-R$ values are shown graphically, and the relationships between the criteria are seen more clearly.

When Figure 2 is analyzed, it is understood that customer satisfaction (C2) at far right of the $x$-axis is of high importance. Since (C14) criterion is in the positive part on the $y$-axis and on the right on the $x$-axis, it can be interpreted as the criterion that affects other performance criteria the most. In the relationship graph, the vertical axis $(y)$ values indicate the direction of the relationship among the criteria. Criteria with positive ( $D$ - 
$R$ ) value are classified as cause criteria and have an impact on effect criteria. In the relationship graph in Figure 1, criteria of C3, C4, C5, C6, C10, C11, and $C 14$, which have positive $(D-R)$ values, are considered as cause criteria and regarded to have an impact on effect criteria of health tourism performance. The criteria of $\mathrm{C} 1, \mathrm{C} 2, \mathrm{C} 7, \mathrm{C} 8, \mathrm{C} 9, \mathrm{C} 12$, and $\mathrm{C} 13$, which have negative $(D-R)$ values, were determined as effect criteria.

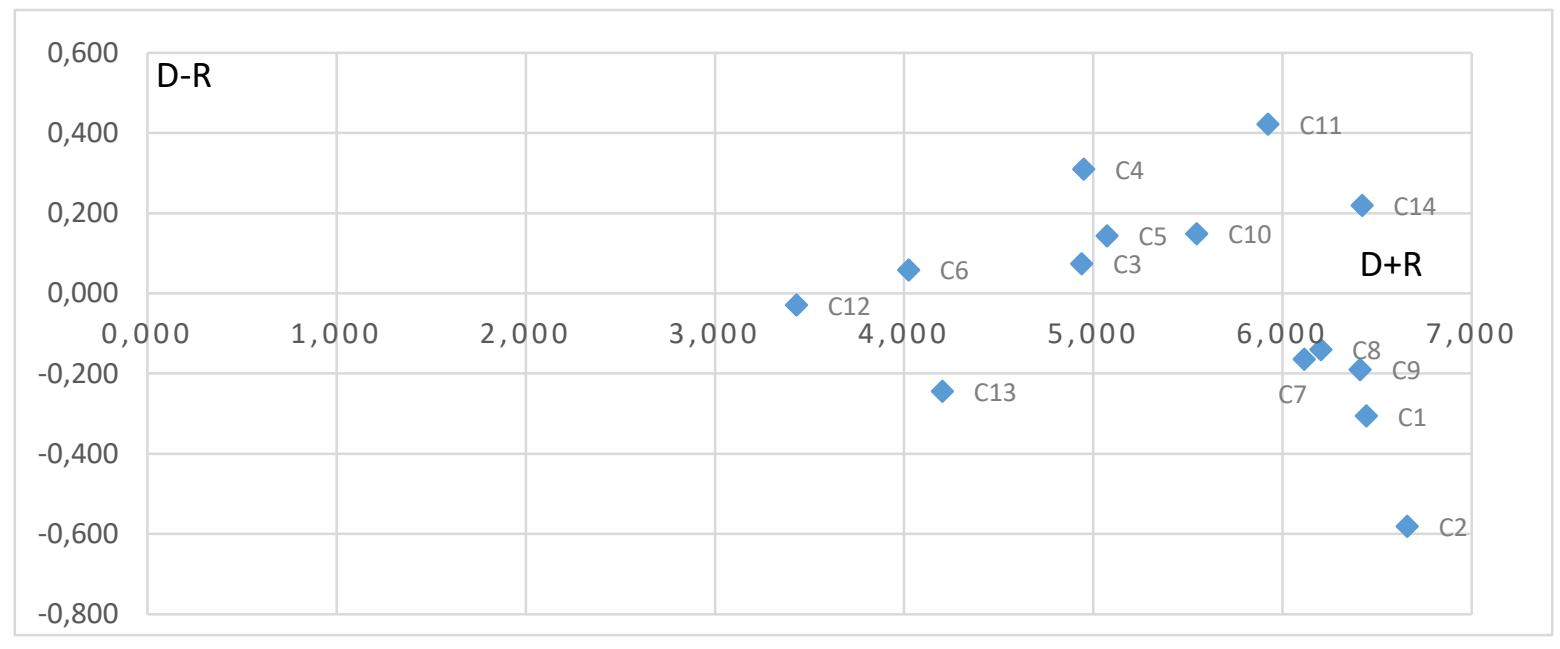

Figure 2. Cause-Effect Relationship Graph

Table 8. Criterion Weights

\begin{tabular}{lcc}
\hline \multicolumn{1}{c}{ Criteria } & w & W \\
\hline C2 Customer Satisfaction & 6.685 & 0.0875 \\
C1 Service Quality & 6.45 & 0.0844 \\
C14 Competition & 6.424 & 0.0841 \\
C9 Price & 6.414 & 0.0839 \\
C8 Financial Performance & 6.204 & 0.0812 \\
C7 Time & 6.117 & 0.08 \\
C11 Flexibility & 5.939 & 0.0777 \\
C10 Supplier Performance & 5.549 & 0.0726 \\
C5 Resource Utilization & 5.073 & 0.0664 \\
C4 Innovation & 4.959 & 0.0649 \\
C3 Safety & 4.939 & 0.0646 \\
C13 Employee Satisfaction & 4.21 & 0.0551 \\
C6 Social Perspective & 4.023 & 0.0526 \\
C12 Environmental Perspective & 3.43 & 0.0449 \\
\hline
\end{tabular}

Criterion weights were calculated using equation 6. Obtained criterion weights values are shown in Table 8 . When the data in Table 8 is examined, it is seen that top three most decisive criteria of health tourism performance are customer satisfaction, service quality, and competition. This ranking is followed by price, time, flexibility, supplier performance, 
resource utilization, innovation, safety, employee satisfaction, social perspective and environmental perspective.

\section{CONCLUSION AND DISCUSSION}

Health tourism draws attention as the highest added value activity area in the tourism sector. The main reasons for this are that participation in health tourism takes place with the desire to be involved in tourist activities as well as receiving treatment and that there is a supportive nature for all other types of alternative tourism. At the same time, seasonality is not the first prominent element in health tourism, and the fact that activities are sustainable for 12 months constitutes a significant plus value for the sector.

It is vital to contribute to continuity of the sector by establishing an assessment infrastructure and determining the essential criteria for measuring health tourism performance. This study aims to contribute to the literature by providing an opportunity to make an internal assessment for the organizations involved in health tourism.

If the service quality assessments of health tourism organizations, which are visited with the desire to feel healthy and well, are carried out regularly, both internally and based on the market, it will contribute to the organization's leadership in performance ranking. The main reason for this is that sustainability of service quality has the power of suppressing many criteria such as price and time on customer perception. The fact that the service quality is the most important factor that customers will focus more, rather than pricing, compared to other tourism activities makes it the most significant and critical criterion by representatives of the industry.

The fact that an organization, known for its service quality, provides customer satisfaction through the transfer of past customer experiences will ensure that the basic motivations of tourists go beyond the more appropriate service procurement. The fact that an organization known for its service quality will provide customer satisfaction through the transfer of past customer experiences will ensure that the basic motivations of tourists go beyond the more appropriate service procurement. It is only in this way that these organizations can compete in the sector.

The innovation criterion, which is another important criterion, ensures the performance of the organization in health tourism to be fully recognized in all aspects and the discovery of all kinds of changes and new service areas. The commitment of health tourism organizations to the innovation criteria is one of the main factors for maintaining their long- 
lasting presence in the sector. The sustainable performance of businesses under competitive pressure is dependent on the fact that they are open and willing to following and implementing global developments in the field of health services they provide. In order to adapt to the market and gain global competitiveness, healthcare organizations need to adopt an innovative approach, especially in product-service.

When the current trends in the health and wellness sector are taken into consideration, it is possible that there can be an increase in the market share of the 'healthy life-oriented consumer' phenomenon. While the perception of wellness is discussed as a temporary phenomenon in other fields of activity of tourism, the mental well-being of people in health tourism has a longer-term effect in relation to physical well-being. Therefore, customer satisfaction in health tourism, which marks more permanent experiences, is among the basic criteria of sustainable performance in the market.

In Turkey, which is one of the leading countries in health tourism, it is possible for businesses to gain added value by assessing both their organizational and sectoral performance and by being aware of problems and developing solutions. Therefore, it is important to focus on qualified personnel training in order to increase the international market share, especially considering that providing quality of service is a multi-faceted process. Also, enhancing travel experiences of tourists through inclusive health tourism packages and making the destination an attractive element will contribute to increasing sustainability. Cooperation and communication networks among organizations providing services in the field of health tourism can make sure that collective decisions are made with the participation of all parties and support regional and national development in solving possible problems in the sector. The inclusion of all actors in a structure that will ensure equal participation, especially in the field of civil society, will enable both the standardization of service quality and the prevention of unequal price policies in financial arrangements among businesses.

\section{Limitations and Suggestions for Future Research}

Considering the limited amount of research on medical tourism in Turkey, it seems necessary to conduct further research. Especially for different stakeholders, the evaluation of the medical tourism industry is important in supporting the development of the sector. Research limitations include time and funding constraints. Another limitation is that the standards used 
within the scope of the study are determined and used based on the literature. Since there is no existing set of evaluation standards for the field of health tourism, an attempt was made to establish a partnership by examining the performance standards of the health and tourism sectors separately, and to incorporate them into the study by seeking expert opinions. However, it may be necessary to re-evaluate existing standards with different expert groups in order to be able to assume full responsibility. The study is limited to department representatives working in institutions operating in the Antalya region. In future studies, the opinions of managers of health tourism companies operating in different regions will be used as guidance to reveal the differences between regions in the performance evaluation of the industry.

\section{REFERENCES}

Aissa, S. B. \& Goaied, M., (2017). Performance of tourism destinations: Evidence from Tunisia. Journal of Hospitality \& Tourism Research,41(7), 797-822.

Altuntaş, S., \& Yılmaz, M. K. (2016). Fuzzy DEMATEL method to evaluate the dimensions of marketing resources: An application in SMEs. Journal of Business Economics and Management, 17(3), 347-364.

Assaf, A. G. \& Josiassen, A. (2012). Identifying and ranking the determinants of tourism performance: A global investigation. Journal of Travel Research, 51(4), 388-399.

Baykaşoğlu, A., Kaplanoğlu, V., Durmuşoğlu, Z. D., \& Şahin, C. (2013). Integrating fuzzy DEMATEL and fuzzy hierarchical TOPSIS methods for truck selection. Expert Systems with Applications, 40(3), 899-907.

Benito, B., Solana, J., \& López P., (2014). Determinants of Spanish regions' tourism performance: A two-stage, double-bootstrap data envelopment analysis. Tourism Economics, 20(5), 73-89.

Bookman, M. Z., \& Bookman, K. R. (2007). Medical tourism in developing countries. New York: Palgrave McMillan.

Çımat, A., \& Bahar, O. (2003). Turkey tourism sector of economy: An assessment of its role and importance. Mediterranean University Faculty of Economics and Administrative Sciences Journal, 6, 1-18.

Croes, R. (2005). Value as a measure of tourism performance in the era of globalization conceptual considerations and empirical findings. Tourism Analysis, 9(4), 255-267.

Deloitte. (2014). Global Health Care Outlook Shared Challenges, Shared Opportunities. Retrieved April 20, 2020, from https://www2.deloitte.com/content/dam/Deloitte/global/Documents/LifeSciences-Health-Care/dttl-lshc-2014-global-health-care-sector-report.pdf.

Díaz, M., R. \&Rodríguez, T. F. E. (2016). Determining the sustainability factors and performance of a tourism destination from the stakeholders' perspective. Sustainability, 8(9), 1-17.

Do, Q. H. \& Chen, J. F. (2013). Prioritizing the factor weights affecting tourism performance by FAHP. International Journal of Engineering Business Management, 5(51), 1-10.

Drăghici, C. C., Diaconu, D., Teodorescu, C., Pintilii, R. D., \& Ciobotaru, A. M. (2016). Health tourism contribution to the structural dynamics of the territorial systems with tourism functionality. Procedia Environmental Sciences, 32, 386-393. 
Erfurt-Cooper, P., \& Cooper, M. (2009). Health and wellness tourism: Spas and hot springs. Bristol: Channel View Publications.

Goodrich, J. N., \& Goodrich, G. E. (1987). Health-care tourism-an exploratory study. Tourism Management, 8(3), 217-222.

GökKısa, A. C. \& Perçin S. (2017). Bütünleşik Bulanık DEMATEL- Bulanık VIKOR yaklaşımının makine seçimi problemine uygulanması. Journal of Yasar University, 12(48), 249- 256.

Han, H., Kiatkawsin, K., Jung, H., \& Kim, W. (2018). The role of wellness spa tourism performance in building destination loyalty: The case of Thailand. Journal of Travel $\mathcal{E}$ Tourism Marketing, 35(5), 595-610.

Heung, V. C., Kucukusta, D., \& Song, H. (2010). A conceptual model of medical tourism: Implications for future research. Journal of Travel $\mathcal{E}$ Tourism Marketing, 27(3), 236251.

Hume, L. F., \& Demicco, F. J. (2007). Bringing hotels to healthcare: A Rx for success. Journal of Quality Assurance in Hospitality \& Tourism, 8(1), 75-84.

İlban, M. O., \&Yıldırım, H. H. (2017). Determination of tourism activities of the world's best tourism destinations using the multi-criteria decision-making method. Cogent Social Sciences,3(1), 1-16.

Kaufmann, A., \& Gupta, M. M. (1991). Introduction to fuzzy arithmetic- Theory and applications. New York: Thomson Computer Press.

Kilavuz, E. (2018). Medical tourism competition: The case of Turkey. International Journal of Health Management and Tourism, 3(1), 42-58.

Lakićević, M., \& Durkalić, D. (2018). Measurement of tourism market performance in EU countries: Results of PROMETHEE-GAIA.3. International Scientific Conference, Serbia.

Li, R.-J. (1999). Fuzzy method in group decision making. Computers $\mathcal{E}$ Mathematics with Applications, 38(1), 91-101.

Lin, C. J., \& Wu, W. W. (2008). A causal analytical method for group decision-making under fuzzy environment. Expert Systems with Applications, 34(1), 205-213.

Liu, C. H., Tzeng, G. H., Lee, M. H., Tseng, H. L., \& Lee, P. Y. (2012). Using a hybrid MCDM model combining fuzzy DEMATEL technique to examine the job stress of coach driver. In J. Watada, T. Watanabe, G. Phillips-Wren, R. Howlett, \& L. Jain (eds), Intelligent Decision Technologies (pp. 149-156). Berlin: Springer.

Loh, C. P. A. (2014). Health tourism on the rise? Evidence from the balance of payments statistics. The European Journal of Health Economics, 15(7), 759-766.

Nair, G. K. (2013). Influence of risk assessment factors on the tourism performance in Qatar: An empirical study. American Journal of Tourism Research,2(2), 141-153.

Niavis, S., \& Tsiotas, D. (2019). Assessing the tourism performance of the Mediterranean coastal destinations: A combined efficiency and effectiveness approach. Journal of Destination Marketing $\mathcal{E}$ Management, 14, 1-11.

Nilashi, M., Samad, S., Manaf, A. A., Ahmadi, H., Rashid, T. A., Munshi, A., Almukadi, W., Ibrahim, O., \& Ahmed, O. H. (2019). Factors influencing medical tourism adoption in Malaysia: A DEMATEL-Fuzzy TOPSIS approach. Computers $\mathcal{E}$ Industrial Engineering, 137(106005), 1-11.

Organ, A. (2013). Bulanık Dematel yöntemiyle makine seçimini etkileyen kriterlerin değerlendirilmesi. Çukurova Üniversitesi Sosyal Bilimler Enstitüsü Dergisi, 22(1), 157172. 
Parida, A., \& Kumar, U. (2006). Applications and case studies maintenance performance measurement (MPM): issues and challenges. Journal of Quality in Maintenance Engineering, 12(3), 239-251.

Reed, C. M. (2008). Medical tourism. Medical Clinics of North America, 92(6), 1433-1446.

Ross, K. (2001). Health tourism: an overview. HSMAI Marketing Review.

Saleh, S. A., Hussain, F., Saud, M. B. B., \& Isa, M. A. M. (2015). Strategic marketing \& competitive analysis of Malaysian medical tourism industry. In Proceeding-Kuala Lumpur International Business, Economics and Law Conference, 6, 61-71.

Seraphin, H., Gowreesunkar, V., Davilla Rodriguez, M. A., \& Davilla Pagan, N. (2018). Assessing the tourism performance of a destination: Toward a new approach using Cuba as a case study. In M. E. Korstanje (Ed.), Critical Essays in tourism research (pp. 71-104). New York: Nova Science.

Sheng-Li, S., Xiao-Yue, Y., Hu-Chen, L., \& Zhang, P. (2018). DEMATEL technique: A systematic review of the state-of-the-art literature on methodologies and applications. Mathematical Problems in Engineering, 1-33.

Smith, M., \& Puczko, L. (2014). Health, tourism and hospitality: Spas, wellness and medical travel. London: Routledge.

Snyder, J., Crooks, V., \& Turner, L. (2011). Issues and challenges in research on the ethics of medical tourism: Reflections from a conference. Journal of Bioethical Inquiry, 8(1), 3-6.

Pnevmatikoudi, K., \& Stavrinoudis, T. (2016). Classification of hotel performance measurement indicators presented in international scientific research. European Journal of Tourism Research, 12, 82-98.

Ribeiro, M. L., Vasconcelos, M. L., \& Rocha, F. (2019). Monitoring performance indicators in the Portuguese hospitality sector. International Journal of Contemporary Hospitality Management, 32(2), 790-811.

Tontus, H. Ö. (2016). Sağlık turizmi tanıtımı ve sağlık hizmetlerinin pazarlanması ilkeleri üzerine değerlendirme. Disiplinlerarası Akademik Turizm Dergisi, 3(1), 67-88.

Turner, L. (2007). Medical tourism: Family medicine and international health-related travel. Canadian Family Physician, 53(10), 1639-1641.

Tzeng, G. H., Chiang, C. H., \& Li, C. W. (2007). Evaluating intertwined effects in e-learning programs: A novel hybrid MCDM model based on factor analysis and DEMATEL. Expert systems with Applications, 32(4), 1028-1044.

Wadongo, B., Odhuno, E., Kambona, O., \& Othuon, L. (2010). Key performance indicators in the Kenyan hospitality industry: A managerial perspective. Benchmarking: An International Journal, 17(6), 858-875.

Wang, S-H., Lee, M-T, Château, P-A., \& Chang, Y-C. (2016). Performance indicator framework for evaluation of sustainable tourism in the Taiwan coastal zone. Sustainability, 8(7), 652.

Wu, W. W. (2008). Choosing knowledge management strategies by using a combined ANP and DEMATEL approach. Expert Systems with Applications, 35(3), 828-835.

Wu, W. W., \& Lee, Y. T. (2007). Developing global managers' competencies using the fuzzy DEMATEL method. Expert systems with applications, 32(2), 499-507.

Zadeh, L. A. (1965). Fuzzy sets. Information and control, 8(3), 338-353.

Zopounidis, C., Baourakis, G., \& Niklis, D. (2010). A comparative study of tourism performance in the Mediterranean region: A multicriteria approach. International Journal of Information and Decision Sciences,2(3), 285-303. 